\title{
Evaluation of the Initial Season for Implementation of Four Tomato Production Systems
}

\author{
Kenneth L. Steffen', Michael S. Dann', Jayson K. Harper', Shelby J. Fleischer ${ }^{3}$, Sizwe S. Mkhize', \\ Doyle W. Grenoble', Alan A. MacNab ${ }^{4}$, and Ken Fager ${ }^{1}$ \\ The Pennsylvania State University, University Park, PA 16802
}

Joseph M. Russo

ZedX, Inc., Boalsburg, PA 16827

Additional index words. Alternaria solani, blossom end rot. compost, cultural practices, economics, irrigation. Leptinotarsa decemlineata, Lycopersicon esculentum, Myzus persicae, mulch, pesticides, root rot, soil amendments, soil fertility, sustainability, trellising

\begin{abstract}
During the initial season of implementation, four tomato production systems differing in soil management, pest control practices, and level of inputs, such as labor, materials, and management intensity were evaluated. These systems were CON, a low input (no mulch, no trellising, overhead irrigation, preplant fertilization, scheduled pest control), conventional agrichemical system; BLD, a high input [straw mulch, trellising, trickle irrigation, compost fertility amendment, integrated pest management (IPM)], ecologically-oriented system that emphasized the building up of soil organic matter levels and used no agrichemicals to supply fertility or for pest control; BLD+, a system similar to BLD, except that agrichemical pesticides were used; and ICM, a high input system (black polyethylene mulch, trellising, trickle irrigation, fertigation,IPM pest control) that used agrichemicals to supply fertility and for pest control. Soil characteristics and fertility levels in the BLD and BLD+ systems were modified with extensive amendments of spent mushroom compost and well-rotted cattle manure. Levels of agrichemical NPK calculated to meet current crop needs were supplied to the CON and ICM systems, with $75 \%$ of fertility in the ICM system supplied through the trickle irrigation lines (fertigation). The BLD system had a greater soil water holding capacity and sharply reduced irrigation requirements. During a wet period, fruit cracking and evidence of water-mold root rot were significantly higher in the ICM system than the BLD and CON systems. Defoliation by Alternaria solani was greatest in the BLD system and least in the ICM system. The BLD and ICM systems resulted in a 1 week earlier peak yield compared to the CON system. The yield of No. 1 fruit was $55 \%$ to $60 \%$ greater in the BLD+ system than the other three systems, which were comparable in yield. Net return was highest in the BLD+ system, although the benefit/cost ratio was greatest in the CON system. This multidisciplinary study has identified important differences in the performance of diverse production systems during the unique transitional season.
\end{abstract}

Recently, there has been growing concern over the impact of current agricultural practices on the natural resource base, on environmental quality, and on farm profitability (National Research Council, 1989a). Much of the current public dialogue on this issue has been taking place in the absence of information on the costs and benefits of alternative production systems, particularly with vegetable crops (National Research Council, 1989b). A multidisciplinary project was initiated in 1990 to evaluate, in replicated tests, the relative ecological, agricultural, and economic viability of vegetable production systems differing in soil and pest management strategies.

Many growers are interested in reducing pesticide use and restoring soils depleted of organic matter, but are concerned that yields and profits will suffer, particularly during the transitional period (Dabbert and Madden, 1986). In a study involving agronomic crops (Culik et al., 1983; Dabbert and Madden, 1986), a transition period of 5 years was required for net rcturns from a

Received for publication 12 Oct. 1993. Accepted for publication 14 June 1994 Contribution no.236 Dept. of Horticulturc. This work was supported by a competitive grant from the College or Agricultural Sciences Research Initiation Grant Program, The Pensylvania State Univ. Use of trade names does not imply endorsement by The Pennsylvania State Univ. We thank Michael Orzolek, Peter Ferretti, and Zane Smilowitz for technical advice and Yildiz Akin for statistical assistance. The cost of publishing this paper was defraycd in part by the payment of page charges. Under postal regulations, this paper therefore must be hereby marked advertisement solely to indicate this fact.

${ }^{1}$ Dept. of Horticulture.

${ }^{2}$ Dept. of Agricultural Economics and Rural Sociology.

${ }^{3}$ Dept. of Entomology.

${ }^{4}$ Dept. of Plant Pathology. system using practices generally considered organic to equal those of a system using conventional practices. The potentially greater returns from high-value horticultural crops, such as vegetables, can justify more extensive modifications of the production environment during the initial year of implementation and possibly allow more abrupt transitions.

In the study presented here, four approaches to crop production differing in their approaches to soil and pest management practices (Table 1) were implemented and evaluated during the unique transitional season. In the two soil-building systems (BLD and BLD+), the soil was amended with high levels of organic matter to dramatically modify the root zone environment and supply fertility. One system (BLD) prohibited the use of synthetic pesticides, while the two integrated pest management (IPM)-based systems (ICM and $\mathrm{BLD}+$ ) reduced pesticide inputs through the inclusion of biological agents for pest control, insect scouting and disease prediction models, and increased tolerance of some losses to disease and insects. Another system (CON) minimized input costs and followed conventional Agricultural Experiment Station recommendations (Orzolek et al., 1990) for fertility and pest management, with pesticides applied on a preventative schedule. The CON system was representative of prior practices employed at this research site and is the starting point for the transition to each of the systems described in this study. While many studies have evaluated one or two cultural practices, few have compared whole systems that differ in their basic production philosophy. In the present study, a multidisciplinary team approach was used to provide a more complete description of these complex crop ecosystems and to provide preliminary information on key elements 
and interactions within crop ecosystems that contribute to the stability, productivity, and profitability of each system during the initial production season.

\section{Materials and Methods}

This study was conducted in 1990 at Penn State University's Russell E. Larson Agricultural Research Center at Rock Springs, Pa. on a 0.4-ha field of Hagerstown silt loam. Red clover was planted in this field the previous growing season. The field was moldboard plowed in Fall 1989 and disked and harrowed in Spring 1990 before the growing season. Calcitic limestone (3.36 $\mathrm{Mg}^{-\mathrm{ha}^{-1} \text { : }}$ $89 \% \mathrm{CaCO}_{3}, 1.6 \% \mathrm{MgO}$ ) was applied to the field 6 weeks before planting. All plots were rototilled 2 weeks before planting to incorporate any soil amendments and again, 3 days before planting for bed preparation. Plot size was $6.1 \times 6.1 \mathrm{~m}$ with $2.3-$ or $3.5-\mathrm{m}$ grass strips between plots. The four production systems are summarized in Table 1. The experimental design was a randomized complete block with three replications. Data were analyzed using a two-way analysis of variance. Statistical differences were determined using Duncan's multiple range test (SAS Institute, 1986).

Soil was analyzed for mineral nutrient content before and after incorporation of chemical fertilizer and organic materiall. In the BLD treatments, the top $20 \mathrm{~cm}$ of soil was amended with 64 dry $\mathrm{Mg} \cdot \mathrm{ha}^{-1}$ of spent mushroom compost (SMC) and 57 dry $\mathrm{Mg} \cdot \mathrm{ha}^{-1}$ of well-rotted cattle manure. The composition. by weight. of SMC was $36.5 \%$ horse manure, $36.5 \%$ timothy mulch hay, $12 \%$ corn cobs, $9 \%$ poultry manure. $3 \%$ cottonseed hulls, and $3 \%$ gypsum. The medium was composted using standard practices for the production of Agaricus bisporus mushrooms before being recycled as a soil amendment. The total $\mathrm{N}$ supplied to each system is presented in Table 2.

Before the development of experimental plots, the field was mapped for soil water holding characteristics at 5 and $25 \mathrm{~cm}$ depths on a $10 \times 10$-m grid and at $15 \mathrm{~cm}$ depth on a $20 \times 20$-m grid to identify field heterogeneity. Volumetric water content was determined in collected soil cores at depths of 15 and $30 \mathrm{~cm}$. Cores representative of each treatment were taken 4.5 weeks after amendment of BLD plots for the generation of soil desorption curves according to Holmes et al. (1967). Meteorological data were collected from a standard weather station located $\approx 150 \mathrm{~m}$ from the treatment plots. Total precipitation. maximum and minimum tenperatures, pan evaporation, and cloud cover were recorded each day at $0800 \mathrm{HR}$. Soil temperature $10 \mathrm{~cm}$ deep was determined weekly at 0800,1200 , and $1600 \mathrm{HR}$ using a thermistor connected to a LI-COR 1000 datalogger (LI-COR, Lincoln, Neb.).

Weather and soil moisture information were used to develop an irrigation schedule for the project following a Food and Agriculture Organization model (Doorenbos and Pruitt, 1977). The schedule was checked weekly by measuring soil moisture in cores at depths of IS. 30 . and $35 \mathrm{~cm}$ and adjusting the irrigation rate accordingly. In the CON plots. available soil moisture in the root zone was maintained above $70 \%$ with overhead irrigation using four Nelson P30 sprinklers (Walla Walla, Wash.). The BLD and ICM plots were irrigated with a twinwall tubing trickle system (Chapin Watermatics, Watertown, N.Y.) with available soil moisture maintained above $80 \%$. All treatments were irrigated to field capacity at each irrigation.

Tomato (Lycopersicon esculentum Mill.) (Asgrow hybrid 724, Bradford, N.J.) seed was sown in a mixture of 2 peatmoss : 1 milled perlite : 1 vermiculite (by volume) on 26 Apr. 1990. Plants were grown in 72-cell size trays (Speedling, Sun City, Fla.) for 6 weeks before transfer to a cold frame for 10 days. Fertilizer solution, 1248-8 (12 g.liter $\left.{ }^{-1}\right)$ was supplied weekly. Seven-week-old plants (15 cm high) were transplanted to the field on 7 June 1990. Starter fertilizer solution, 12-48-8 (70 g.liter ${ }^{-1} 0.5$ liter/plant), was used during transplanting. Plant height, stem diameter. and number of leaves per plant were determined for selected plants at weekly intervals for the first 5 weeks after transplanting.

Plants in the ICM and BLD systems were trellised $\approx 4$ weeks after transplanting (Konsler and Gardner, 1990). The CON plots were not trellised. The ICM and BLD plots used 1.2-m row spacing with $0.45-\mathrm{m}$ intrarow spacing to five a density of 18,000 plants/ha. The CON system used $1.5-\mathrm{m}$ row spacing and $0.6-\mathrm{m}$ intrarow spacing for a density of 10,800 plants/ha. The ICM plots used 122$\mathrm{cm}$ wide black polyethylene mulch $(25-\mu \mathrm{m}$-thick embossed, Leco Films of Canada). The BLD system used $\approx 12,000 \mathrm{~kg}$ wheat straw mulch/ha. spread $10 \mathrm{~cm}$ thick and $75 \mathrm{~cm}$ to either side of the row. No mulch was used in the CON plots.

Total nitrogen (Isaac and Johnson. 1976) and mineral nutrient content (Dahlquist and Knoll. 1978) were determined on tomato leaflets from the second and third fruit cluster from the plant apex while the fruit were still green (Hochmuth et al.. 1991). Samples were taken from ICM and BLD plots only. Leaf curling or wilting. an indicator of visually diagnosed water-mold root rot, and fruit cracking in the ICM, BLD. and CON treatments were evaluated 1 week after a period of heavy rain in August 1990. The incidence of blossom end rot (BER) was also determined during weekly harvests.

A census of Colorado potato beetle (CPB). Leptinotarsa

Table 1. Description of key Cultural practices used in tomato production systems.

\begin{tabular}{lcclccc}
\hline \hline Systern & Irrigation & Fertilization & Mulch & Population & Trellising & Pest control \\
\cline { 4 - 6 } & Trickle & Fertigation & Plastic & $18,000 / \mathrm{ha}$ & Yes & Synthetic-biological \\
BLD & Trickle & Compost & Straw & $18,000 / \mathrm{ha}$ & Yes & Botanicals-biological \\
BLD+ & Trickle & Compost & Straw & $18.000 / \mathrm{ha}$ & Yes & Synthetic-biological \\
CON & Overhead & Preplant & None & $10,800 / \mathrm{ha}$ & No & Scheduled synthetic \\
\hline
\end{tabular}

Table 2. Fertilization of tomato production systems.

\begin{tabular}{|c|c|c|c|}
\hline System & Source & Form & Nitrogen content \\
\hline ICM & $10-10-10$ & Banded & $30 \mathrm{~kg} \cdot \mathrm{ha} \mathrm{I}^{\prime}$ \\
\hline & $20-20-20$ & Fertigated & $90 \mathrm{~kg} \cdot \mathrm{ha}{ }^{\prime}$ \\
\hline BLD \& BLD+ & $\begin{array}{l}\text { Mushroom compost and } \\
\text { well rotted manure }\end{array}$ & $\begin{array}{l}8 \mathrm{~cm} \text { Incorporated } \\
\text { into } 50 \mathrm{~cm} \text { soil }\end{array}$ & $\begin{array}{c}2700 \mathrm{~kg} \text { Organic N/ha } \\
134 \mathrm{~kg} \mathrm{NH}{ }_{+} \mathrm{N} / \mathrm{ha}\end{array}$ \\
\hline $\mathrm{CON}$ & $10-10-10$ & Banded & $120 \mathrm{~kg} \cdot \mathrm{ha}^{-1}$ \\
\hline
\end{tabular}




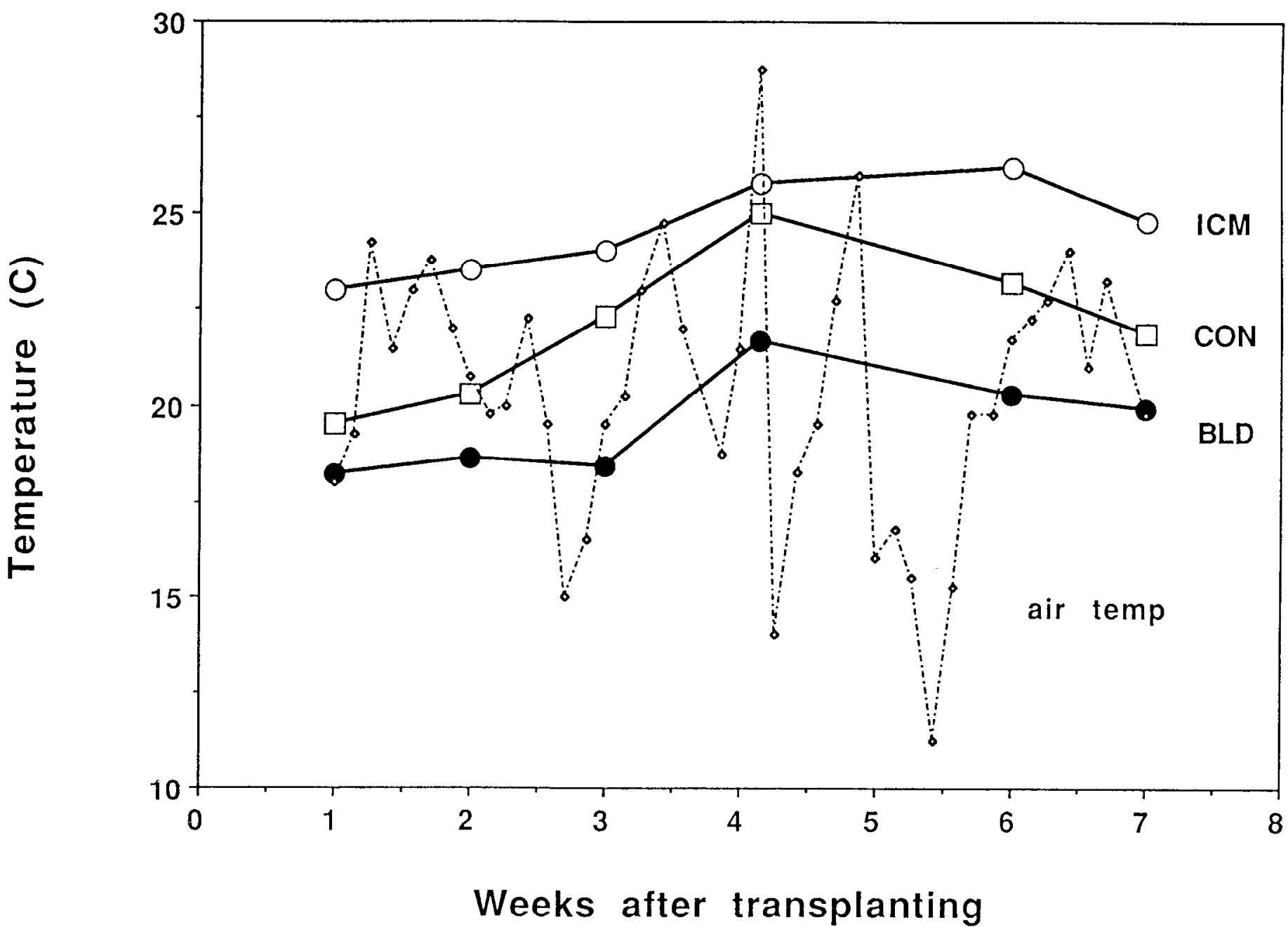

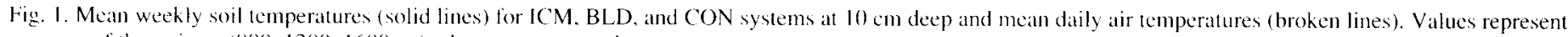
means of three times $(800,1200,1600)$ HR $)$ taken once per week.

decemlineatta (Say), and green peach aphid (CPA) [Myzus persicae (Sulz.)], was taken weekly from 20 June to 31 Aug. 1990. Eight plants in each replication were inspected for the presence and density of each species and insecticides applied to individual plots when thresholds were exceeded. In the BLD system, to control $\mathrm{CPB}$, the following biological or botanical materials were used: (Bacillus thuringiensis var. san diego) (Trident, EC, 12 liters $\cdot \mathrm{ha}^{-1}$, Knoll Bioproducts Co., Santa Fe, Minn.) or rotenone (Rotenox, EC, 6 liters.ha ${ }^{-1}$, Ciba-Geigy, Greensboro, N.C.). Where appropriate for the treatment, systemic organics were used to control GPA [endosulfan (Thiodan, WP, $1 \mathrm{~kg} \cdot \mathrm{ha}^{-1}$, Fairfield American Corp., Rutherford, N.J.) or oxamyl (Vydate, liquid, 5 liters $\cdot \mathrm{ha}^{-1}$, CibaGeigy, Greensboro, N.C.).

For control of early blight (Alternaria solani), a computerized forecasting system for tomato known as FAST (Madden et al.. 197X) was used. This program identifies periods when environmental conditions are favorable for development of early blight and provides a schedule for efficient applications of the fungicide chlorothalonil (Bravo 720.2 liters $\cdot$ ha $^{-1}$, emulsion, Fermenta ASC, Mentor. Ohio). The program was used in the ICM, CON, and BLD+ treatments. No sprays were used for disease control in the BLD treatment. High plant vigor and disease avoidance were relied upon to minimize the impact of early blight. Defoliation was assessed (Horsfall and Barrett, 1945) at weekly intervals beginning 17 Aug. when 5\% defoliation was evident in the no-fungicide treatment. For control of broadleafweeds, metribuzin (Sencor DF, $0.2 \mathrm{X} \mathrm{kg} \cdot \mathrm{ha}^{-1}$, Mobay, Kansas City, Mo.) was applied once after the tomatoes were transplanted in the ICM and $\mathrm{CON}$ treatments.

Tomatoes were harvested from each plot at six weekly intervals from 21 Aug. to 26 Sept. 1990. At each harvest, fruit were picked from twelve plants, six plants from each of two previously chosen rows. All fruit at any stage of ripeness from red to breaker were picked. Using U.S. Dept. Agriculture (1976) standards fruit were separated into culls and two grades, US No. 1 and US No. 2. Fruit were also categorized based on size. All yield data from the sampling area was converted to a per-hectare basis.

To compare costs and returns of the various production systems, crop budgets were constructed using a budget generator (Spurlock and Laughlin, 1987). Benefit-cost ratios were calculated to evaluate the relative efficiency of dollars spent on inputs for their ability to generate income in the various production systems (Sassone and Schaffer, 1978). Net economic return was determined by subtracting the costs of all inputs (including labor, equipment, materials, and interest on operating capital) from the income from outputs, determined from yield and quality of fruit. Labor included time for all field operations including tillage, irrigation setup, mulch laying, planting, staking and trellising, pest management, and postharvest cleanup. Materials included costs of seed, fertilizer, pesticides, irrigation materials and water, compost, etc. Cost of labor was assessed at $\$ 7.00 / \mathrm{h}$. Harvest and handling 
Table 3. Mineral nutrient status and $\mathrm{pH}$ of the soil.

\begin{tabular}{lcccccc}
\hline System & $N^{*}$ & $\mathrm{P}$ & $\mathrm{K}$ & $\mathrm{Ca}$ & $\mathrm{Mg}$ & $\mathrm{pH}$ \\
\hline \multicolumn{7}{c}{ Beforefertilization } \\
ICM & $--{ }^{*}$ & $184 \mathrm{a}$ & $332 \mathrm{a}^{\times}$ & $3400 \mathrm{a}$ & $317 \mathrm{a}$ & $6.1 \mathrm{a}$ \\
BLD & -- & $176 \mathrm{a}$ & $313 \mathrm{a}$ & $3230 \mathrm{a}$ & $311 \mathrm{a}$ & $6.0 \mathrm{a}$ \\
CON & -- & $174 \mathrm{a}$ & $362 \mathrm{a}$ & $3520 \mathrm{a}$ & $326 \mathrm{a}$ & $6.3 \mathrm{a}$ \\
\multicolumn{7}{c}{ End of season } \\
ICM & $1.45 \mathrm{~b}$ & $218 \mathrm{~b}$ & $313 \mathrm{~b}$ & $4860 \mathrm{~b}$ & $361 \mathrm{~b}$ & $6.6 \mathrm{~b}$ \\
BLD & $2.31 \mathrm{a}$ & $370 \mathrm{a}$ & $1800 \mathrm{a}$ & $5740 \mathrm{a}$ & $484 \mathrm{a}$ & $7.1 \mathrm{a}$ \\
CON & --- & $205 \mathrm{~b}$ & $492 \mathrm{~b}$ & $4570 \mathrm{~b}$ & $367 \mathrm{~b}$ & $6.6 \mathrm{~b}$
\end{tabular}

${ }^{2} \mathrm{~N}$ values in $\mathrm{mg} \cdot \mathrm{g}^{-1}$, others in $\mathrm{kg} \cdot \mathrm{ha}^{-1}$.

${ }^{y}$ Not determined.

${ }^{x}$ Mean separation within columns and times by Duncan's multiple range test $(P=0.05)$.

Table 4. Mineral composition of leaf tissue from the ICM and BLD production systems.

\begin{tabular}{lccccr}
\hline & \multicolumn{6}{c}{ Percent of leaf tissue } \\
\cline { 2 - 6 } System & $\mathrm{N}$ & $\mathrm{P}$ & $\mathrm{K}$ & $\mathrm{Mg}$ & $\mathrm{Ca}$ \\
\hline ICM & $4.23 \mathrm{a}^{y}$ & $0.30 \mathrm{~b}$ & $3.05 \mathrm{~b}$ & $0.51 \mathrm{a}$ & $3.30 \mathrm{~b}$ \\
BLD & $3.62 \mathrm{~b}$ & $0.57 \mathrm{a}$ & $4.27 \mathrm{a}$ & $0.55 \mathrm{a}$ & $4.80 \mathrm{a}$ \\
Optimal range & $3.0-5.0$ & $0.3-0.6$ & $3.0-5.0$ & $0.3-0.5$ & $1.0-2.0$
\end{tabular}

${ }^{2}$ Values are means of two leaf samples.

${ }^{y}$ Mean separation within columns by Duncan's multiple range test $(\mathrm{P}=0.05)$.

${ }^{\mathrm{x}}$ Hochmuth et al. (1991).

costs were charged at $\$ 0.077 / \mathrm{kg}$ fruit $(\$ 0.035 / \mathrm{lb})$. Income was based on yield and quality of fruit. In 1990, the average price for fresh market tomatoes on the wholesale market in Pennsylvania was $\$ 0.438 / \mathrm{kg}(\$ 0.199 / \mathrm{lb})$. Only No. 1 fruit were included in income calculations. Potential income from No. 2 tomatoes was projected to be low and quite variable; expenses for their harvest and handling are included, however, in calculating net returns. The addition of compost and manure provided crop benefits for several years (unpublished data). In the economic analysis, the entire cost of these materials and application costs were included in the expenses for the first year in one analysis and amortized over 3 years in a second analysis.

\section{Results and Discussion}

In this initial production season, the different management strategies implemented in the four production systems resulted in significant differences in soil temperature, soil water holding capacity, soil and plant nutrient content, disease and insect levels, physiological disorders, yield, produce quality. and net income. Soil temperatures throughout the season were highest in the ICM system beginning 1 week after transplanting and were generally lowest in the BLD system (Fig. 1 ). On warm days, heated air rising from plant holes in the black polyethylene mulch was observed to result in some transplant wilting, even though available soil water was high. Diurnal soil temperature fluctuations (not shown) were smallest in the BLD system, indicative of a buffering effect of the straw mulch and soil amendment (Unger, 197X). Beginning 2 weeks after transplanting, height, stem diameter, and number of leaves in plants from the ICM system were significantly greater than plants from the CON system, with plants from the BLD system intermediate (data not shown). Many researchers have noted the positive effects of black polyethylene mulch on early yield of tomatoes (Taber, 1983; Perry and Sanders, 1986), a phenomenon generally attributable to increased soil temperatures (Ashworth and Harrison, 1983). While the use of black polyethylene mulch in the ICM system resulted in higher soil temperatures, it did not increase earliness of yield. Differences in earliness may have been observed had we established tomato plants 2 or 3 weeks earlier, although 1 June is the frost free date for this location. Plants in the BLD system continued to grow and develop new flushes of light-green leaves after vegetative growth had ceased in plants from both the ICM and CON systems. This new growth was visible until fruit ripening was initiated and may reflect midseason increases in availability of nutrients from organic sources.

The soil amendments in the BLD system supplied the fertility requirements of the crop and would be expected to alter soil physical and chemical properties. Soil in the BLD system had significantly higher levels of $\mathrm{N}, \mathrm{P}, \mathrm{K}, \mathrm{Ca}$, and $\mathrm{Mg}$ and a higher $\mathrm{pH}$ at the end of the season than the ICM and CON systems (Table 3). Despite the high soil $\mathrm{N}$ content in the BLD system from the organic matter amendment, $\mathrm{N}$ content in plants at early bloom was $-20 \%$ lower in leaf samples from the BLD system than the ICM system. While high soil $\mathrm{N}$ levels represent a potential nitrate leaching problem, a study on sand soils in Connecticut demonstrated that $-2000 \mathrm{~kg} \mathrm{~N} / \mathrm{ha}$ from 112 dry $\mathrm{Mg} \cdot \mathrm{ha}^{-1}$ of SMC resulted in one-half the nitrate leaching as did $146 \mathrm{~kg} \mathrm{~N} / \mathrm{ha}$ from conventional fertilizer (Maynard, 1989). In the Connecticut study, nitrate concentrations in the groundwater beneath the conventionally fertilized plots reached $14.7 \mathrm{ppm}$, exceeding the $10-\mathrm{ppm}$ drinking water standard. Nitrate concentrations beneath SMC plots, however, peaked at $6.3 \mathrm{ppm}$.

In this study, high soil $\mathrm{P}$ and $\mathrm{K}$ levels in the BLD systems resulted in leaf tissue concentrations of $\mathrm{P}$ and $\mathrm{K}$ that were $\approx 2$-fold and 1.4-fold higher, respectively, than in leaf tissue from the ICM system (Table 4). High soil levels of macronutrients such as $\mathrm{K}$ have been shown to improve fruit quality (size and appearance) and yield of tomatoes (Mullins and Coffey, 1982). The SMC used in the BLD and BLD+ systems contained limestone chips that would have increased the reaction buffering capacity of the soil, although manures without added limestone can raise soil $\mathrm{pH}$ and increase buffering capacity (Long et al.. 1975). Calcium concentrations were $\approx 1.5$-fold higher in leaf samples from the BLD system as compared to leaf tissue from the ICM and CON systems, reflecting the magnitude of the soil differences. The addition of organic matter such as SMC or manure offers the additional benefit of increasing $\mathrm{pH}$ to the point where liming is unnecessary, although without restraint, soil $\mathrm{pH}$ levels can be raised above 7 where $\mathrm{P}$. Mn, and $\mathrm{B}$ begin to become relatively unavailable for plant uptake (Lucas and Davis. 1961).

Soil properties, such as bulk density and percentage of small pore space, improve with the addition of SMC (Wang et al., 1984), thus altering soil water holding characteristics. Soil water desorp tion curves (Brady, 1990) were constructed early in the season for each of the different systems using soil cores to determine water holding capacities (data not shown) between field capacity $(0.01$ $\mathrm{MPa})$ and the permanent wilting point $(1.5 \mathrm{MPa})$. Total available soil water (top $10 \mathrm{~cm}$ ) was $0.145,0.135$, and $0.107 \mathrm{~cm} \mathrm{H}_{2} \mathrm{O} / \mathrm{cm}$ soil for the BLD, ICM, and CON systems. respectively. Elevated levels of soil organic matter in the BLD system increased soil water holding capacity as has been observed in previous studies (Arshad and Coen, 1992). The greater water holding capacity of unamended soils in the ICM as compared to the CON system was apparently due to less compaction of freshly tilled soil by water movement under the polyethylene mulch in the ICM system (Emert, 1957). Direct measurements of soil moisture indicated that the polyethylene mulch excluded precipitation events of $<1.3 \mathrm{~cm}$ from the root zone; rainfall below this threshold was not included in the crop 

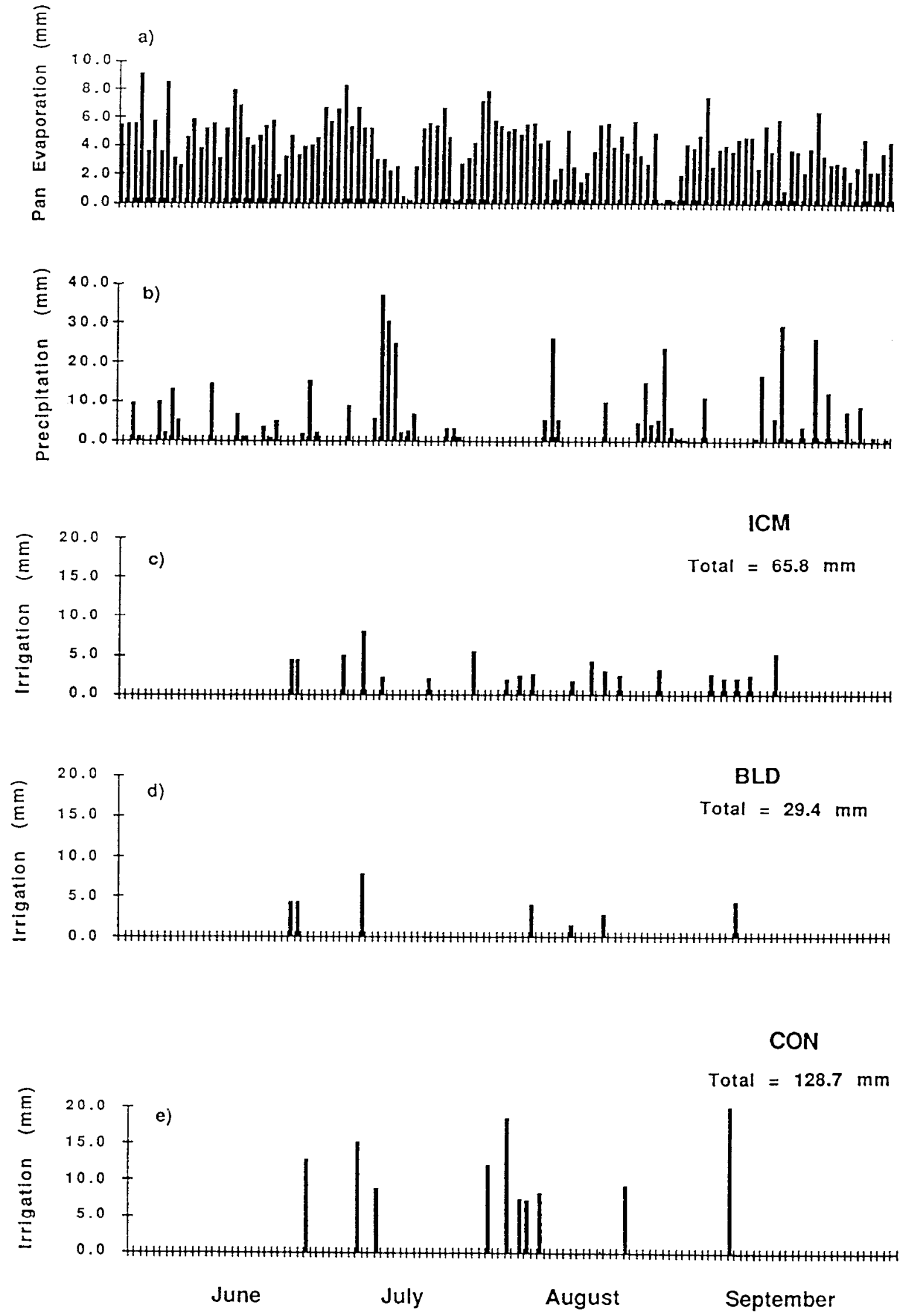

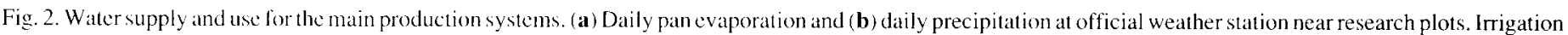

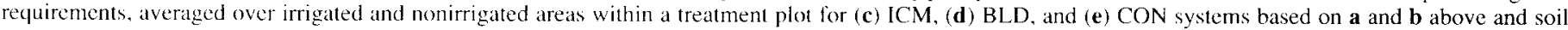
desorption curves and crop coeflicients. 
Table 5. Evaluation of leaf wilting or curling' and fruit cracking I week after a heavy rain (August 1990).

\begin{tabular}{lcc}
\hline \hline System & Wilting $^{y}$ & Cracking $^{*}$ \\
\hline ICM & $2.0 \mathrm{a}^{\mathrm{w}}$ & $9.2 \mathrm{a}$ \\
BLD & $1.0 \mathrm{~b}$ & $1.0 \mathrm{~b}$ \\
CON & $0.2 \mathrm{c}$ & $1.4 \mathrm{~b}$ \\
\hline
\end{tabular}

${ }^{2}$ Wilting and curling were indicative of visually diagnosed water mold root rot. 'Leaf curling and wilting was evaluated using a scale 0 to $5(0=$ no curling or wilting, $5=$ whole plant curling or wilting).

${ }^{x}$ No. of fruit per 12-plant sample. Values are means of treatments with three replications.

"Mean separation within columns by Duncan's multiple range test $(P=0.05)$.

Table 6. Fruit yield of tomato production systems

\begin{tabular}{|c|c|c|c|c|c|}
\hline \multirow[b]{2}{*}{ System } & \multicolumn{2}{|l|}{$\begin{array}{c}\text { Marketable } \\
\text { yield }\end{array}$} & No. 2 & $\begin{array}{l}\text { Large } \\
\text { fruit }^{2}\end{array}$ & Culls \\
\hline & & $\left(\mathrm{Mg} \cdot \mathrm{ha}^{-1}\right)$ & & (\% tota & yield?) \\
\hline$\overline{\mathrm{ICM}}$ & $80.9 a^{x}$ & $42.6 \mathrm{~b}$ & $38.3 \mathrm{a}$ & $82.8 \mathrm{a}$ & $21.4 \mathrm{a}$ \\
\hline BLD & $73.2 \mathrm{ab}$ & $39.6 \mathrm{~b}$ & $33.6 \mathrm{ab}$ & 78.93 & $19.1 \mathrm{ab}$ \\
\hline BLD+ & $102.4 \mathrm{a}$ & $71.0 \mathrm{a}$ & $31.4 \mathrm{ab}$ & $81.6 \mathrm{a}$ & $10.6 \mathrm{~b}$ \\
\hline $\mathrm{CON}$ & $62.5 \mathrm{~b}$ & $39.0 \mathrm{~b}$ & $23.5 \mathrm{~b}$ & $66.0 \mathrm{a}$ & $23.0 \mathrm{a}$ \\
\hline
\end{tabular}

${ }^{2}$ Fruit $>62 \mathrm{~mm}$ in diameter.

${ }^{\text {y }}$ Total yield $=$ marketable yield + culls.

'Mean separation within columns by Duncan's multiple range test $(\mathrm{P}=$ 0.05). Values are means of three replications. water budget for the ICM system. Differences in infiltration rates were observed between systems during heavy rains, when considerable surface water washed off of the ICM plots, and to a lesser degree, the CON plots, causing some sheet erosion. No surface water runoff was evident in the BLD or BLD+ plots. The result of these differences, and the greater water delivery efficiency of trickle versus overhead irrigation (Bernstein and Francois, 1973), was that the BLD system required one half the irrigation water of the ICM system and only one-fourth of the irrigation water of the CON system (Fig. 2). Seasonal irrigation requirements for each system were 294.0, 658.4, and 1,287.2 $\mathrm{m}^{3} \mathrm{H}_{2} \mathrm{O} /$ ha for BLD, ICM, and $\mathrm{CON}$, respectively.

Following an unusually wet period, plant wilting and leaf curling was observed throughout the field (Table 5). A water-mold root rot, commonly associated with water-logged soils, was visually diagnosed in affected plants. The ICM system was most severely affected, with some plant mortality, while the CON system was least affected. A significantly greater amount of fruit cracking, indicative of a fluctuating water supply, occurred in fruit from the ICM system compared with the other systems (Table 5). Fruit with BER constituted $\approx 4 \%, 1.5 \%$, and $0.7 \%$ of the total yield in fruit from the ICM, CON, and BLD systems, respectively. BER is aggravated by low or fluctuating soil moisture, high $\mathrm{K}$ and $\mathrm{NH}$,$\mathrm{N}$, and low Ca levels (Pill and Lambeth, 1980; Mullins and Wolt, 1983). The impermeable polyethylene mulch not only excluded precipitation as indicated above, but also greatly retarded the loss

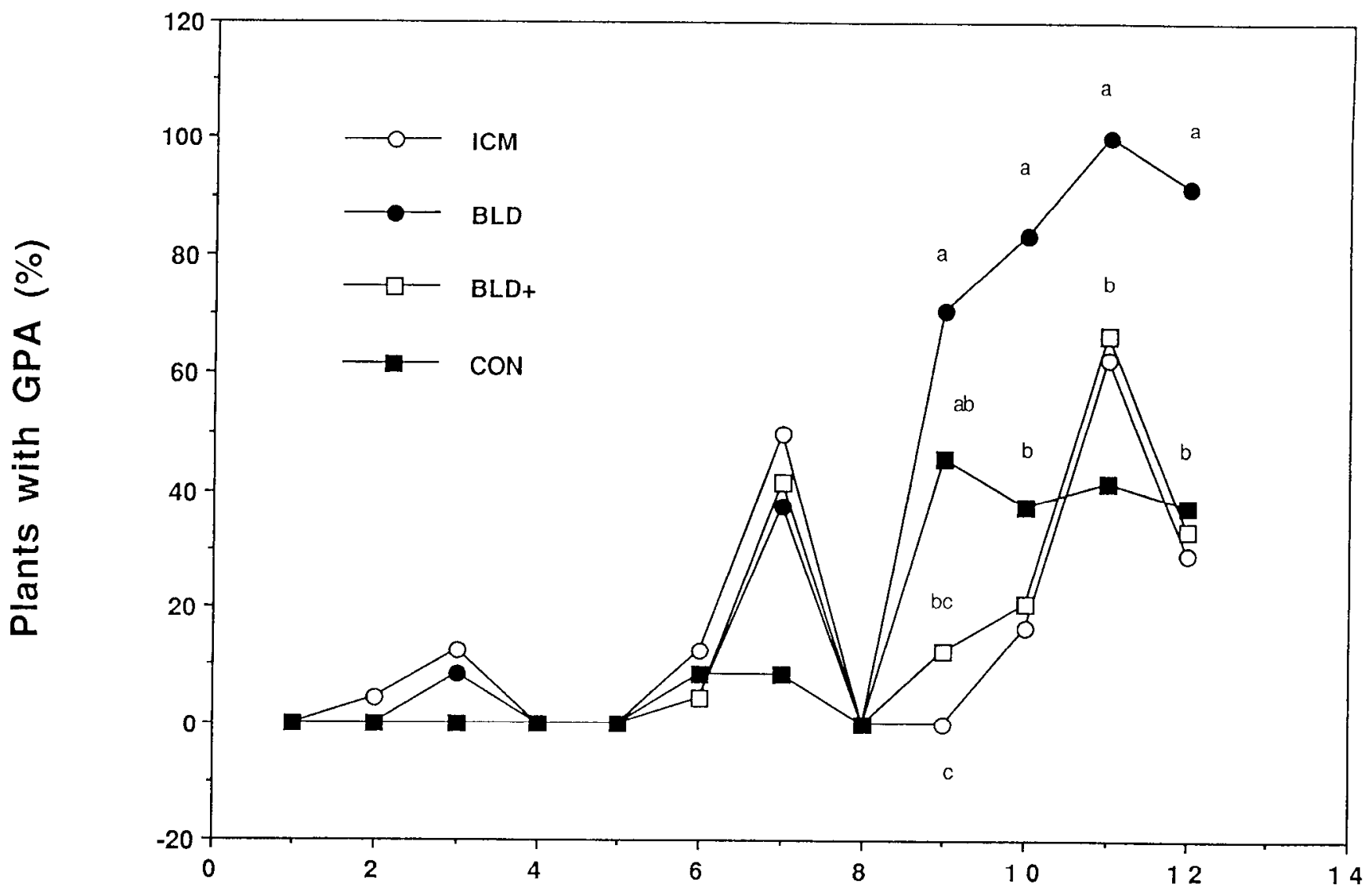

\section{Weeks after transplanting}

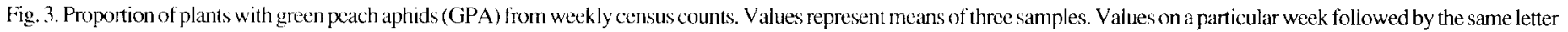
are not significantly different (Duncan's multiple range test, $P=0.05$ ). Plants were field-transplanted on 7 June 1990 ). 


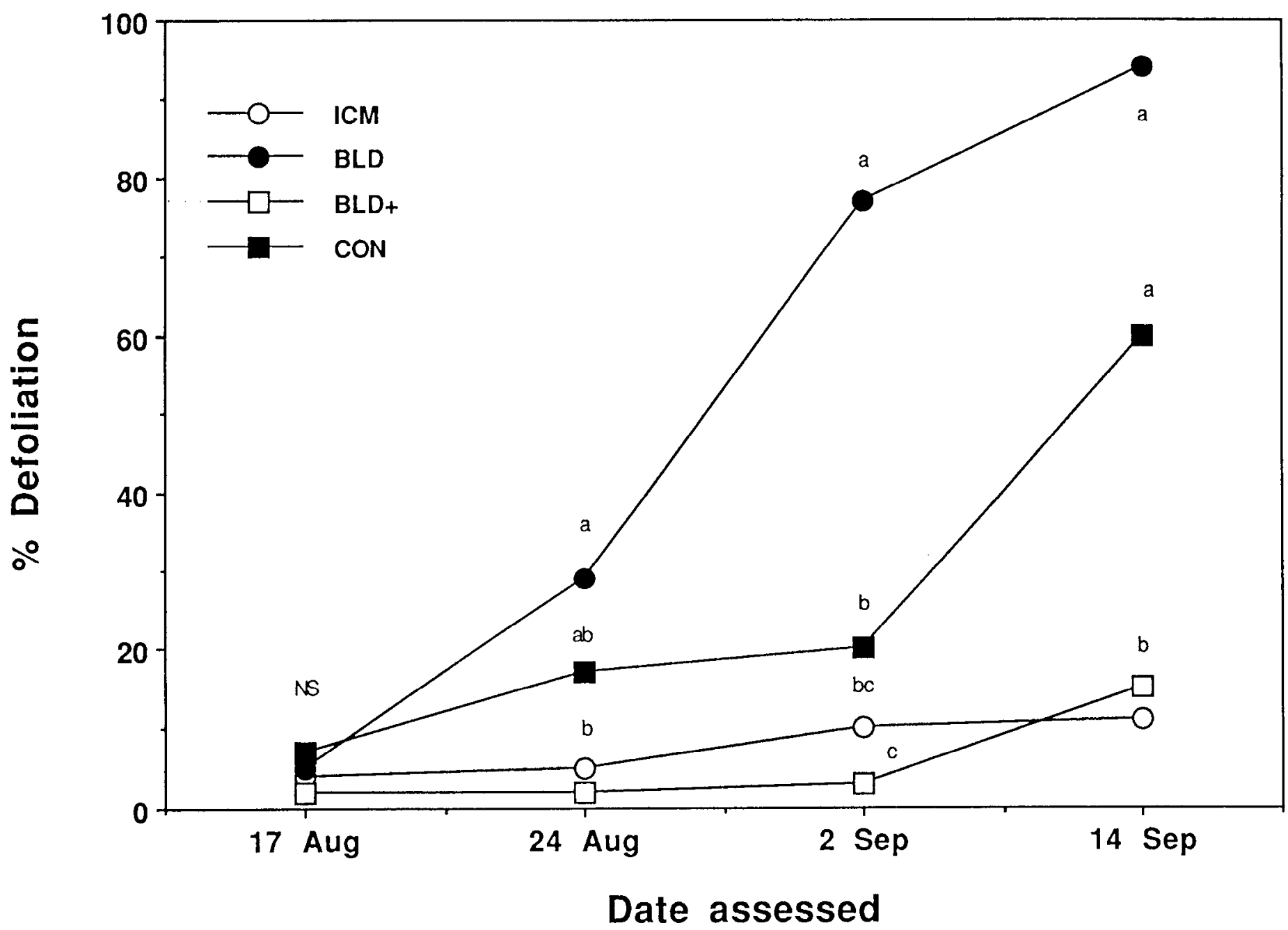

Fig. 4. Defoliation of tomato plants in the four production systems. Assessment (based on Horsfall and Barrett, 194.5) began 4 weeks after first detection of early blight symptoms. Values represent means of three samples. Values on a particular date followed by the same letter are not significantly different (Duncan's multiple range test, $P=0.05) ;{ }^{\mathrm{NS}}$ nonsignificant.

of water from mulched soils following saturation by periods of heavy rain. We have indirect evidence for greater incidence or severity of water mold root rot under the polyethylene mulch (Table 5). We hypothesize that the loss of root hairs to disease with the initiation of new root hairs as water-logged soils dried resulted in fluctuations in plant available water and nutrients such as $\mathrm{Ca}$ even though soil levels were adequate. This scenario could explain the greater fruit cracking (Table 5) and BER incidence in the ICM system. Perry and Sanders (1986) noted increased total yields of large and marketable fruit but also a high proportion of cull tomato fruit using black polyethylene mulch. Although we did not observe differences in proportions of large fruit with respect to type of mulch, the percentage of culls was lower in the amended and strawmulched systems (Table 6).

CPBs were observed 3 weeks after transplanting but were essentially absent by 7 weeks posttransplant. There was no significant difference in the proportion of plants infested, or in adult beetle density (data not shown). The BLD plots, however, had a consistently higher infestation rate in weeks 3,5 , and 6 , and densities of immature stages were significantly higher in the BLD plots on one date, 6 weeks after transplanting (data not shown). These patterns were not related to insecticide applications; the CON treatments had no insecticides for CPB control, and the other treatments had one or two applications of biological insecticides.
Low populations of GPA were present within 2 weeks after transplanting and significant populations began to build starting 6 weeks after transplanting (data not shown). This later increase may have been a second generation. Systemic organic insecticides were selectively applied beginning on 25 July (-7 weeks after transplanting) to control aphids in the CON, ICM, and BLD+ systems. Of the four dates between 25 July and 31 Aug. and the three replications per treatment (i.e., twelve potential plots that could be sprayed per treatment), from five to seven plot-dates were sprayed in each treatment except the BLD plots. Aphid controls were withheld from the BLD plots, except for one plot-date application applied erroneously. Beginning on 10 Aug. 1990, the ninth weekly count, and continuing until the twelfth and last count, the proportion of plants with GPA was significantly higher in the BLD system (Fig. 3). Also, the proportion of plants above the threshold of $20 \mathrm{GPA} /$ plant was higher in the BLD system from the tenth to the last count (data not shown). Thus, insecticide applications correlated with lower GPA densities.

Defoliation from early blight was slow to develop in 1990 and occurred in the latter half of the production season. No fungicide was used to control early blight in the BLD system and significant defoliation occurred by the end of August compared with the other systems (Fig. 4). In early September, plants in the BLD system had more than three times the defoliation of the other systems. The 
difference continued until mid-September, when a marked increase in the defoliation of plants in the CON system also occurred. In contrast. plants in the ICM system, which used the same fungicide program, were not markedly defoliated. This situation may be related to poorer spray coverage of nontrellised CON plants and increased duration of moisture on the foliage due to overhead irrigation and slower drying in the nontrellised canopy. In BLD+, where fungicide was used to control early blight, defoliation was low and similar to that in the ICM system (Fig. 4). The FAST treatment did not perform as well on nontrellised plants as in previous studies for two reasons. In this study, a fungicide was used at the lowest instead of the highest recommended rate for the FAST program. Also, wet conditions prevented fungicide applications during a 14-day period when two applications at S-day intervals were indicated.

Wang et al. (1984) observed increased yields of tomato and cucumber under field conditions by adding SMC. The ICM, BLD, and CON systems did not differ significantly in total marketable yield or yield of No. 1 fruit (Table 6) nor in the percentage of large fruit (greater than $62 \mathrm{~mm}$ ), although potential productivity was likely constrained in the BLD system by extensive defoliation. Plants from the BLD+ system, which had SMC-amended soil but also effective early blight control, had a significantly higher yield of No. 1 tomatoes than those from the other systems and a higher yield of total marketable fruit than plants from CON plots. Slight fruit cracking or catfacing were common defects that caused fruit to be downgraded to No. 2. Yield of No. 2 fruit from plants in the ICM system was higher than from plants of the CON system. In the BLD system. many of the No. 2 grade fruit had defects such as concentric ring scars, poor shape and color, green shoulders, and slightly cracked stem ends. The concentric rings and poor color could have resulted from the exposure of fruit to excess light and heat after defoliation or greater exposure to the sun because of trellising. Kretchman (1990) reported that fruit exposed to excess sunlight and high temperatures fail to develop red color. We have noted in a related study that lycopene, a red pigment, is lower in

Table 7. Yield of tomatoes fruit by harvest date.

\begin{tabular}{lcccccc}
\hline \hline \multicolumn{7}{c}{$\begin{array}{c}\text { Harvest date } \\
\left(\mathrm{Mg} \cdot \mathrm{h} \mathrm{a}^{-1}\right)\end{array}$} \\
\cline { 2 - 7 } System & 21 Aug. & 28 Aug. & 5 Sept. & 12 Sept. & 19 Sept. & 26 Sept. \\
\hline ICM & $\mathbf{1 . 9} \mathrm{a}^{y}$ & $6.1 \mathrm{ab}$ & $19.7 \mathrm{a}$ & $10.3 \mathrm{a}$ & $8.9 \mathrm{a}$ & $23.4 \mathrm{ab}$ \\
BLD & $1.9 \mathrm{a}$ & $11.2 \mathrm{a}$ & $35.4 \mathrm{a}$ & $31.1 \mathrm{a}$ & $8.7 \mathrm{a}$ & $4.9 \mathrm{~b}$ \\
BLD+ & $0.5 \mathrm{a}$ & $10.5 \mathrm{a}$ & $26.4 \mathrm{a}$ & $20.9 \mathrm{a}$ & $16.2 \mathrm{a}$ & $27.8 \mathrm{a}$ \\
CON & $0.9 \mathrm{a}$ & $3.6 \mathrm{~b}$ & $11.4 \mathrm{~b}$ & $16.0 \mathrm{a}$ & $13.0 \mathrm{a}$ & $11.1 \mathrm{ab}$
\end{tabular}

${ }^{\overline{2}}$ Yield of No. 1 and No.2 grade tomatoes.

'Mean separation within columns by Duncan's multiple range test $(\mathrm{P}=$ 0.05). Values are means of three replications.

Table 8. Economic analysis of tomato production systems.

\begin{tabular}{lccccccc}
\hline System & Fungicide & $\begin{array}{c}\text { Plant } \\
\text { density }\end{array}$ & $\begin{array}{c}\text { Yield No. } 1 \\
\left(\mathbf{M g - h a}^{-1}\right)\end{array}$ & $\begin{array}{c}\text { Gross income } \\
(\$ / \mathrm{ha})\end{array}$ & $\begin{array}{c}\text { Expenses } \\
(\$ / \mathrm{ha})\end{array}$ & $\begin{array}{c}\text { Net return } \\
(\$ / \mathrm{ha})\end{array}$ & $\begin{array}{c}\text { Benefit-cost } \\
\text { ratio }\end{array}$ \\
\hline ICM & Yes & High & 42.6 & 18,570 & 13,980 & $4,590 \mathrm{bc}$ & $1.31 \mathrm{bc}$ \\
CON & Yes & Low & 39.0 & 17,070 & 8,580 & $8,490 \mathrm{ab}$ & $\mathbf{1 . 9 9} \mathrm{a}$ \\
BLD & No & High & 39.6 & 17,330 & 16,940 & $390 \mathrm{c}$ & $1.02 \mathrm{c}$ \\
BLD+ & Yes & High & 71.0 & 31,040 & 19,590 & $11,450 \mathrm{a}$ & $1.58 \mathrm{ab}$ \\
BLD+ $^{2}$ & No & High & 30.6 & 17,330 & 14,140 & $3,190 \mathrm{bc}$ & $1.23 \mathrm{bc}$ \\
BLD $^{2}$ & Yes & High & 71.0 & $3 \mathbf{1 , 0 4 0}$ & 16,790 & $14,250 \mathrm{a}$ & $1.85 \mathrm{a}$
\end{tabular}

${ }^{\overline{7}}$ Alternative assumption: costs for soil amendment amortized over 3 years instead of I year; expenses include one-third the total cost of amendment. fruits from trellised production systems (unpublished data). The percentage of cull fruit in the BLD+ plots was significantly less than in the ICM and CON plots. Many of the culls in the BLD system had evidence of fungal infection.

Several trends were observed in weekly yield per harvest date (Table 7). Production in the CON system lagged behind the other systems by at least 1 week. Weekly yields in the BLD and BLD+ systems were similar until the last harvest when nearly complete defoliation dramatically reduced yield in the BLD system. While total yield (Table 6) in the ICM and BLD + systems was similar. weekly yields fluctuated more widely in the ICM system, a further indication of an uneven water supply. Starting at the third weekly harvest both the BLD+ and CON systems had relatively consistent weekly yields, though the higher average yields in the BLD+ systems contributed to a statistically significant difference in total yields between the systems (Table 6).

The BLD+ system (addition of organic matter, trickle irrigation, staking, and use of pesticides) had the highest input expense of any treatment, provided the greatest income, and resulted in the highest net return (Table 8). Plant stress from biotic agents, primarily due to early blight, and perhaps also due to green peach aphid, dramatically reduced income in the BLD system, leading to the lowest net return. Yield and resulting gross income were comparable for ICM, BLD, and CON systems. The CON system had the least external inputs (no mulch or staking, lower cost for irrigation materials) and had the highest return of these three treatments. Benefit-cost ratios for the study varied from 1.02 for the BLD treatment to 1.99 for the CON treatment (Table 8). Although the income from the ICM, CON, and BLD systems was similar, the expenses for the BLD treatment were about twice as high as those for CON.

WC have studied the residual beneficial effects of these initial soil amendments in the BLD systems over an additional 2 years and three different vegetable crops and have observed increased crop yield and quality with no additional fertilizer added (unpublished data). If the costs of SMC and manure (about \$4,200/ha) in the BLD system are amortized over 3 years, the observed length of its effect on soil fertility, the expenses in the BLD and BLD+ systems decrease to $\$ 14,140 /$ ha and $\$ 16,790 /$ ha, respectively. Consequently, the net return per hectacre increases dramatically in the BLD treatment and increases by » $25 \%$ for the BLD+ treatment. If growers adopted a production system on the basis of total net return alone, it would be expected that they would select a system like that represented by treatment BLD+. Growers select a production system not only on its potential profitability, but also on such factors as how it affects labor availability, how it fits into existing crop enterprises, and how it affects farm economic risk. The selection of a system like that represented by CON may appear more desirable in the short term for many producers because of the lower demands it places on labor, management, and finances.

Several other factors, including postharvest storability and 
consumer acceptance, may also influence the economic viability of these production systems. In postharvest evaluations from this study (unpublished data), fruit from the BLD system were intermediate in storability compared to the ICM system, which was the highest and CON system, which was the lowest. In consumer taste tests, the flavor of fruits from the BLD system was rated lower than that from the ICM and CON systems (unpublished data). While these factors do not have a dollar value that can be easily included in a benefit-cost analysis, they will have an impact on the merit of each system. Environmental costs must also be considered in assessing true costs to different management approaches. It is difficult, however, to assign a monetary value to costs incurred by soil erosion, excessive water use or nutrient losses, and adverse environmental impacts. The development of realistic costs for the impact of agricultural production systems on the natural resource base and the environment is critical if we are to assess the longterm sustainability of agricultural practices accurately.

This study has provided a relatively comprehensive description of the performance of four different tomato production systems during the transitional production season. It has also provided preliminary information on the following outcomes.

a) Extensive inputs of organic matter as a soil amendment and a mulch resulted in significant increases in productivity and profitability if pesticides were also used.

b) The combination of soil amendment and straw mulch resulted in a marked decrease in water consumption due to greater capture of precipitation and a greater storage capacity. This combination also demonstrated better water supply characteristics as reflected in reduced root disease and fruit cracking, as compared to an unamended system that used polyethylene mulch.

c) Extensive compost amendment resulted in increased nutrient composition in early bloom tomato leaf tissue for a number of essential elements, but a decrease in $\mathrm{N}$ levels.

Related studies have examined the postharvest quality of tomato fruit from these systems (unpublished data) and have followed the effects of the initial extensive compost amendment in 1990 over 3 years and four different vegetable crops (unpublished data). Work in progress includes on-farm studies of the effects of extensive compost amendments on productivity and profitability as well as long-term field plot studies of the effects of extensive compost amendments designed to abruptly alter soil properties and smaller amendments, designed to meet crop fertility needs, on soil, plant, and groundwater parameters.

\section{Literature Cited}

Arshad, M.A. and G.M. Coen. 1992. Characterization of soil quality: Physical and chemical criteria. Amer. J. Alt. Agr., 7:25-31.

Ashworth, S. and H. Harrison. 1983. Evaluation of mulches for use in the home garden, HortScience 18: 180-182.

Bernstein, L. and L.E. Francois. 1973. Comparisons of drip, furrow, and sprinkler irrigation. Soil Sci. 115:73-86.

Brady. N.C. 1990. The nature and properties of soils. 10th ed. Macmillan, New York.

Culik, M.N.. J.C. McAllister, M.C. Palada. and S. Rieger. 1983. The Kutztown farm report: A study of a low input crop/livestock farm. Regenerative Apr. Tech. Bulletin, Rodale Research Center, Kutztown, Pa.

Dabbert, S. and P. Madden. 1986. The transition to organic agriculture: A multi-year simulation model of a Pennsylvania farm, Amer. J. Alt. Agr.
1:99-107.

Dahlquist, R.L. and J.W. Knoll. 1978. Inductively coupled plasma atomic emission spectrometer: Analysis of biological materials and major, trace, and ultra-trace elements. Applied Spectroscopy 32:1-29.

Doorenbos, J. anti W.O. Pruitt. 1977. Guidelines for predicting crop water requirements. Irri. and Drainage Paper No. 24 (revised). Food and Agri. Org. of the United Nations. Rome.

Emert, E.M. 1957. Black polyethylene for mulching vegetables. Proc. Amer. Soc. Hort. Sci. 69:464-469.

Hochmuth, G. D. Maynard, C. Vavrina, and E. Hanlon. 1991. Plant tissue analysis and interpretation for vegetable crops in Florida. Univ. of Fla. Ext. Pub. SS-VEC-42.

Holmes, J.W., S.A. Taylor, and S.J. Richards. 1967. Measurement of soil water, p 275-303.In: R.M. Hagan, H.R. Haise. and T.W. Edminster (eds.). Irrigation of agricultural lands. Agron. Ser. No. 11.

Horsfall, J.G. and R.W. Barrett. 1945. An improved grading system for measuring plant diseases. Phytopathology 35:655.

Isaac, R.A. and W.C. Johnson. 1976. Determination of total nitrogen in plant tissue, using a block digestor. J. AOAC 59:98-100.

Konsler, T.R. and R.G. Gardner. 1990. Commerical production of staked tomatoes in North Carolina, North Carolina Agr. Ext. Publ. AG-405.

Kretchman, D. 1990. Tomato disorders are preventable. Amer. Veg. Grower 38(8):14-17.

Long, F.L., Z.F. Lund, and R.E. Hermanson. 1975. Effect of soilincorporated dairy cattle manure on runoff water quality and soil properties, J. Environ. Qual. 4:163-166.

Lucas, R.E. and J.F. Davis. 1961. Relationships between $\mathrm{pH}$ values of organic soils and availabilities of 12 plant nutrients. Soil Sci. 92:17182.

Madden, L., S.P. Pennypacker. and A.A. MacNab. 1978 FAST. a forecast system for Alternaria solani on tomato, Phytopathology 68: 1354-1358.

Maynard, A.A. 1989. Agricultural composts as amendments reduce nitrate leaching from soil. Frontier $\backslash$ of Plant Science. Connecticut Agr. Expt Sta. no. 42, p 2-4.

Mullins, C.A. and D.L. Coffey. 1982. Effect of fertilizer level and season on tomato fruit quality. Tennessee Farm and Home Sci. no. 3. pp 9-13.

Mullins. C.A. and J.D. Walt. 1983. Effects of calcium and magnesium lime sources on yield, fruit quality, and elemental uptake of tomato. J. Amer. Soc. Hort. Sci. 108:850-854.

National Research Council. 1989a. Alternative agriculture. National Academy Press, Washington. D.C.

National Research Council. 1989b. Investing in research: A proposal to strengthen the agriculture, food. and environment system. National Academy Press. Washington. D.C.

Orzolek, M.D.. P.A. Ferretti. A.A. MacNab. Z. Smilowitz, R. Cole, D.W. Grenoble, W.K. Hock, and D.R. Daum. 1990. Commerical vegetable production recommendations: Pennsylvania. Penn State Coop. Ext.. The Pennsylvania State Univ., University Park. Pa.

Perry, K.B. and D.C. Sanders. 1983. Tomato yield as influenced by plant protection systems. HortScience 21:238-239.

Pill, W.G. and V.N. Lambeth. 1980. Effects of soil water regime and nitrogen form on blossom-end rot, yield, water relation5. and elemental composition of tomato. J. Amer. Soc. Hort. Sci. 105:730-734.

SAS Institute. 1986. SAS user's guide. SAS Institute, Cary, N.C.

Sassone, P.G. and W.A. Schaffer. 1978. Cost-benefit analysis: A handbook. Academic Press. New York.

Spurlock, S.R. and D.H. Laughlin. 1987. Mississippi state budget generator user's guide. version 2.0. Agr. Econ. Tech. Publ. No. 64, Mississippi State Univ., May 1987.

Taber, H.G. 1983. Effect of plastic soil and plant covers on Iowa tomato and muskmelon production. Proc. Natl. Agr. Plastics Conf. 17:37-45.

Unger, P.W. 1978. Straw mulch effects on soil temperature and sorghum germination and growth. Agron. J. 70:858-864.

U.S. Dept. of Agriculture. 1976. United States standards for grades of fresh tomatoes. 41 F.R. 11464.

Wang, S.H., V.I. Lohr, and D.L. Coffey. 1984. Spent mushroom compost as a soil amendment for vegetables. Amer. Soc. Hort Sci. 109:698-702. 